\title{
EDITORIAL
}

\section{DESARROLLAR ESTUDIOS DE IMPACTO CLÍNICO-RADIOLÓGICO: VITAL PARA LA ESPECIALIDAD}

Para nadie es un misterio que nuestra especialidad ha ido creciendo en importancia en el proceso diagnóstico, y en la medida que hacemos mejor nuestro trabajo interpretando correctamente los estudios, los clínicos se apoyan cada vez más en nuestra labor. Sin embargo, eso se acompaña del interés de otras especialidades de involucrarse en la ejecución e interpretación de las imágenes, lo que conlleva el riesgo de desplazar al radiólogo, o abiertamente ocupar el espacio que se ha dejado abandonado.

Nuestra especialidad debe equiparar el enorme desarrollo tecnológico que nos permite adquirir imágenes más rápidas, de mejor calidad y más precisas, con la necesidad de imprimirle un sello de utilidad clínica y en procesos de toma de decisión. Sólo en la medida que los radiólogos se involucren activamente en los grupos de especialidad, y se integren como parte de aquellos que toman decisiones en beneficio de nuestros pacientes, nuestra especialidad mantendrá el sitial que se ha ganado y merece.

Por ello, es que hay una ventana de oportunidad para desarrollar estudios en campos de decisión clínica, o como el impacto de la incorporación de las imágenes generan un cambio en la conducta terapéutica. El desarrollar habilidades para poder conducir estudios de estas características idealmente debiera surgir desde el entrenamiento médico, pero de no darse así, durante la formación de post-grado de nuestros residentes debiera considerarse como esencial. Si los radiólogos solo nos incorporamos a la investigación que realizan los otros especialistas como colaboradores, estamos retrocediendo.

Sin dudas que existe una dificultad en desarrollar investigación de calidad cuando nos enfrentamos a la creciente carga de trabajo en nuestras instituciones, sin embargo, aquellas que se han embarcado en un proyecto académico, tienen la obligación moral de proveer las herramientas necesarias para su desarrollo, en particular para las generaciones en formación.

El Congreso Chileno de Radiología es una oportunidad para permitir que los radiólogos y residentes de radiología presenten su investigación aplicada al campo de las imágenes, ya sea como evaluación de pruebas diagnósticas, estudios descriptivos, de pronostico o terapéuticos. Este año, se ha decidido dar mayores facilidades y opciones para dar difusión a la investigación naciente en nuestro país, que se darán a conocer a la brevedad. Esperamos una activa participación de la comunidad radiológica, y que consideren sus trabajos para difusión en nuestra Revista.

Dr. Claudio Silva Fuente-Alba

Editor Científico

Revista Chilena de Radiología 